\title{
中国戈壁综合自然区划研究
}

\author{
申元村 ${ }^{1}$, 王秀红 ${ }^{1^{*}}$, 程维明 ${ }^{2}$, 吴金凤 ${ }^{1,3}$, 卢 琦 ${ }^{4}$, 冯益明 4
}

(1. 中国科学院地理科学与资源研究所,陆地表层格局与模拟院重点实验室,北京 100101;

2. 资源与环境信息系统国家重点实验室, 中国科学院地理科学与资源研究所, 北京 100101;

3. 中国科学院大学, 北京 $100049 ; 4$. 中国林业科学院荒漠化研究所, 北京 100091)

\begin{abstract}
摘 要: 中国戈壁广泛分布于北方的干旱与极干旱区域, 直至目前尚未系统地开展戈壁分区研究。本文在综合分析 戈壁特征与形成发生机制关系后认为, 我国戈壁的最主要特征是地表砾质覆盖; 表层具孔状漆漠结皮,其下具棕红 色紧实层及石膏层; 植物覆盖度极低, 生长旱生极旱生灌木一半灌木。戈壁形成发生的区域仅限于干燥度 4 以上 的干旱、极干旱区域。根据戈壁特征及发生条件的区域分异, 选取干温指标、区域地质地貌建造指标、地表物质成 因形态指标, 将中国戈壁分布区划分为温性干旱极干旱戈壁区、暖性干旱极干旱戈壁区和青藏高原北部亚寒干旱 极干旱戈壁区 3 个一级区 (区), 其下按区域地质地貌建造特征划分出 9 个二级区(地区), 再按戈壁地表物质成因与 形态差异划分出 19 个三级区(亚地区)。还可根据土壤和植被的地域分异进一步划分出若干个四级区(小区)。
\end{abstract}

关 键 词:戈壁; 干旱与极干旱区域; 综合自然区划

1 引言

从区域角度观察和研究地域综合体, 依据环境 与资源的区域差异进行区域单元的划分, 被称为地 理区划(郑度等, 2005)。中国区划研究从 1929年竺 可桢发表《中国气候区域论》, 黄秉维 1940 年开展中 国植被区划, 李旭旦 1947 年发表《中国地理区域之 划分》为先导, 经 20 世纪 50 年代中国科学院组织全 国开展综合自然区划, 区划工作便进人全面发展时 期。目前, 全国性区划方案、部门区划方案、区域区 划方案已较完备, 成果显著, 在促进地理学科发展, 服务国家社会经济建设作出了重要贡献(郑度等, 2005)。中国干旱区研究以沙漠与沙地形成及防 治、水资源特征与合理利用为核心, 成果更为突出, 但以戈壁为独特对象进行的区划研究, 虽也有极少 量涉及, 却仍未见系统分区研究成果, 本文试图就 此进行探讨(赵松乔, 1985; 赵松乔等, 1990; 朱俊凤 等, 1999; 卢琦, 2000; 吴正, 2009; 申元村等, 2013)。

\section{2 戈壁基本特征及形成发生条件}

\section{1 戈壁基本特征}

戈壁, 又称砾漠,源自蒙古语“难生草木的土 地”, 特指具有独特地理景观的土地 (王伯恭, 1999)。基本特征主要为: 地面由砾石、砂砾覆盖; 土壤发育微弱, 石膏化过程和积盐过程突出, 表层 具极不稳定的孔状结皮,其下为棕红色紧实层及石 膏层; 植被覆盖稀疏, 盖度通常不足 $10 \%$, 生长早 生、极旱生灌木一半灌木植物。

\section{2 形成发生条件}

戈壁上述特征是在特定地理条件下形成的: 它 形成发生于中国西北内陆腹地、太阳辐射强烈、年 降水量通常不足 $200 \mathrm{~mm}$ 、蒸发量高于 $2000 \mathrm{~mm}$ 、干 燥度大于 4 的区域,干旱、极干旱为其发生的前提条 件;地表砾质覆盖体源于高原面剥蚀残积或山麓坡 积一洪积侵蚀堆积; 土壤发育微弱, 具有独特的戈 壁土壤发生特征: 表层砾面为铁锰风化而形成的膜

收稿日期: 2015-10; 修订日期:2015-12。

基金项目:林业行业公益项目(201404304); 测绘地理信息公益性行业科研专项(201512033) [Foundation: Forestry Nonprofit

Specific Project, No.201404304; Surveying and Mapping Geoinformation Nonprofit Specific Project, No.201512033]。

作者简介: 申元村(1941-), 男, 广东兴宁市人, 研究员, 主要从事自然地理综合研究, E-mail: shenyc@igsnrr.ac.cn。

通讯作者:王秀红(1964-), 男,山西昔阳人,博士,副研究员,主要从事土地资源研究,E-mail: wangxh@igsnrr.ac.cn。

引用格式: 申元村, 王秀红, 程维明, 等. 2016. 中国戈壁综合自然区划研究[J]. 地理科学进展, 35(1): 57-66. [Shen Y C, Wang X H, Cheng W M, et al. 2016. Integrated physical regionalization of stony deserts in China[J]. Progress in Geography, 35(1): 57-66.]. DOI: 10.18306/ dlkxjz.2016.01.007 
状漆皮层,亚表层为铁质氧化并被染色而形成的褐 棕色或红棕色紧实层, 其下为石膏化和盐积化形成 的石膏积聚层或石膏盐盘层, 石膏积聚层的形成也 是戈壁土壤的主要特征之一(熊毅等, 1990); 植物生 境严酷, 只能生长稀疏旱生、超旱生灌木、半灌木和 草本, 覆盖度极低, 生态环境十分脆弱, 一旦破坏极 难恢复。

\section{3 中国戈壁分区原则、指标与戈壁综 合自然区划}

\section{1 分区原则}

依据区划必须反映戈壁地域分异规律,服务区 域社会经济发展和生态建设的目标要求, 中国戈壁 区划遵循如下原则:

3.1.1 地带性与非地带性分异相结合的原则

戈壁形成发生仅限于地球表层的特定地域, 在 大尺度地域分异格局上其分布受纬度地带与距海 远近的制约, 因而在分区原则上首先必须考虑地带 性因素。然而, 戈壁本身又是非地带性景观, 反映 的是地方(局地)地域特征, 因此, 对戈壁进行区域单 元划分时, 必须采用地带性与非地带性相结合的原 则。在具体进行区域单元划分时, 首先应把地带性 温度和水分差异放在第一位, 建造地面砾质覆盖的 地质地貌等非地带性因素次之。

3.1.2 戈壁地理区发生的同一性与区内特征相对一 致性原则

戈壁形成发生有其相应的区域特征,划分出的 区划单位, 其内部应具有发生学上的统一性, 地貌 过程、气候过程、水文、土壤、植被等过程具有同一 性, 区内自然特征应是相对一致的区域。

3.1.3 综合性与主导因素相结合的原则

任何区划单位, 不论高级单位还是低级单位, 都是各地理要素相互作用形成的区域统一体, 但在 构建地域单元特征过程中, 各地理要素所起的作用 又是不相同的, 往往其中一二个因子起着突出主导 作用。划分地域单元时, 应该在全面分析各要素相 互作用基础上, 找出起主导作用的要素, 这样才能 揭示区域分异的本质。不同级的区划单位, 主导因 素会有所不同。在戈壁形成与发育过程中, 高级区 划单位的要素中, 干、温气候因素通常起着主导作 用; 中低级区划单位形成中, 地质地貌建造单元与 砾质覆盖体特征往往起主导作用。因此, 主导因素 便成为区划分级的主要指标。突出主导因素, 亦有
利于区划单位的命名。

3.1.4 为生态建设提供科学依据的原则

戈壁分布区域广阔，不同戈壁区域间均有自身 的环境问题，治理对策和恢复技术亦应分区而异。 戈壁区划将能有针对性地为制定区域生态防治技 术和实施途径提供科学依据。

3.1.5 为戈壁资源综合开发和戈壁区经济发展提供 服务的原则

戈壁区虽然生态环境十分脆弱, 生态资源较为 贫乏,但仍蕴藏着十分丰富的自然资源。在保护戈 壁生态前提下,合理和适度利用这些自然资源, 不 仅不会破坏戈壁生态,反而会有利于促进戈壁区生 态环境与社会经济协调发展。戈壁区域矿产资源 丰富, 也有一定数量的特色生物资源, 具有广阔的 开发前景。特色生物资源如梭梭可发展成为梭梭 一肉丛蓉产业, 药用植物资源如麻黄、锁阳、黄芪、 霸王, 食饮植物资源如沙棘、白刺、泡泡刺, 绿化美 化观赏盆栽资源如补血草、兔唇花、神香草、慢黄罂 粟、多花柽柳、枸杞、疏花蓄薇、金丝桃叶绣线菊、郁 金香、鸢尾等都具有开发价值,可形成产业,开发潜 力巨大(潘晓玲等, 2001)。

\section{2 区划指标}

戈壁的发生与地域分异的必要条件是干旱和 地表砾质覆盖, 以及与之相匹配耦合的漠境土壤与 植被。由此确定的区划指标如下:

3.2.1 气候干温系统指标

戈壁仅发生分布与中国西北干旱区和青藏高 原北部干旱、特干旱区域。依据郑度等(2007)的研 究成果, 本文采用的温度指标与干湿状况指标如表 1 所示。经过温度与干燥指数的区域耦合, 中国戈 壁区域可划分为温性干旱极干旱戈壁区、暖性干旱 极干旱戈壁区、青藏高原北部亚寒性干旱极干旱戈 壁区。

\subsection{2 地貌建造指标}

戈壁地面砾质覆盖体只发育在干旱、极干旱区 高原剥蚀残原和山体洪积冲积扇粗砾质堆积体上, 地貌形势归属于 7 大地貌单元和 19 个区域地貌基 本形态区。大地貌单元是戈壁形成发生的基本框 架, 区域地貌基本形态区是戈壁分区的基本单元。 地貌建造指标如表 2 。

\subsection{3 戈壁砾质覆盖体成因类型指标}

戈壁砾质覆盖体的成因界定对于揭示戈壁的 地域分区有特殊意义,对划分戈壁基本地域单元有 重要指示作用,并成为划分第三级区划单元的主要 
表 1 戈壁分布区域温度带与干湿状况划分指标

Tab.1 Temperature zone and aridity-humidity conditions in the stony desert regions in China

\begin{tabular}{|c|c|c|c|c|}
\hline \multirow{2}{*}{ 温度带 } & \multicolumn{2}{|c|}{ 主要指标 } & \multirow{2}{*}{ 干湿状况 } & \multirow{2}{*}{ 干燥度 $K$ 值 } \\
\hline & $\geqslant 10^{\circ} \mathrm{C}$ 积温日数 $/ \mathrm{d}$ & $\geqslant 10^{\circ} \mathrm{C}$ 积温数值 $/{ }^{\circ} \mathrm{C}$ & & \\
\hline 寒温带 & $<100$ & $<1600$ & 湿润环境 & $<1.00$ \\
\hline 中温带 & $100 \sim 170$ & $1600 \sim 3200(3400)$ & 半湿润环境 & $1.00 \sim 1.50$ \\
\hline 暖温带 & $170 \sim 220$ & $3200(3400) \sim 4500(4800)$ & 半干旱 & $1.50 \sim 4.00$ \\
\hline 高原温带 & $50 \sim 180$ & $1600 \sim 3200$ & 干旱 & $>4.00$ \\
\hline 高原亚寒带 & $<50$ & $<1100$ & 极干旱* & $>8.00$ \\
\hline
\end{tabular}

"极干旱,戈壁内部分异确立的指标。

指标。根据砾质覆盖体的成因, 可将戈壁砾质覆盖 体划分为剥蚀残积和侵蚀堆积两大成因类型(赵松 乔, 1985)。剥蚀残积砾质覆盖体的主导成因是风 蚀作用, 它将高原细粒物质吹走后, 残留下粗砾状 物质而成为戈壁, 规模宽广, 坦荡无垠为其重要特 征。侵蚀堆积砾质覆盖体主要成因是水蚀作用, 它 将粗砾物质积聚于山麓坡积一洪积扇上, 成带状分 布于山前, 条带状分布为其重要特征。在主导成因 下, 其它成因也往往会互相叠加, 如在剥蚀高原面 上, 由于小地貌临时水流侵蚀作用, 会伴随洪积堆 积作用的发生, 在山麓山洪侵蚀堆积体上, 伴随着 残积坡积的发生。不同的成因过程, 往往有相应的 砾质类型体, 如碎石、砾质、砂砾质等。砾质覆盖体 的成因类型如表 3 。

\section{4 区划系统}

根据以上区划原则、指标体系及地域系统, 可 将中国戈壁区域划分为 3 级。第 1 级以气候干温系 统为依据划分出 3 个区; 第 2 级以区域地貌基本形 态单元为依据划分出 9 个地区; 第 3 级以戈壁砾质 覆盖体成因及砾型划分出 19 个亚地区。分区系统 如表4、图1。

\section{5 戈壁区基本特佂}

\section{I 温性干旱极干旱戈壁区}

该区指中温带干燥度大于 4 区域内的戈壁分布 区,含内蒙古高原西部干旱戈壁地区、阿拉善高原 干旱极干旱戈壁地区、河西走廊东中部干旱极干旱 戈壁地区、北疆盆地干旱极干旱戈壁地区(郑度, 2015)。

\section{1 内蒙古高原西部干旱戈壁地区}

该地区位居内蒙古高原西部的干旱区域,位于
表 2 中国戈壁分布区大地貌单元与地貌基本形态分区

Tab.2 Geomorphologic units and basic geomorphologic forms in the stony desert regions in China

\begin{tabular}{ll}
\hline \multicolumn{1}{c}{ 大地貌单元 } & \multicolumn{1}{c}{ 区域地貌基本形态区 } \\
\hline 1.内蒙古高原 & 1.1 内蒙古高原西部高原 \\
2.鄂尔多斯高原 & 2.1 鄂尔多斯西部贺兰山东麓山前平原 \\
3.阿拉善高原 & 3.1 乌兰布和高地 \\
& 3.2 腾格里高地 \\
& 3.3 巴丹吉林高地 \\
& 3.4 雅玛雷克高原 \\
& 3.5 居延盆地台地 \\
4.河西走廊凹陷平原 & 4.1 石羊河流域中下游平原 \\
& 4.2 黑河流域中下游平原 \\
& 4.3 疏勒河流域中下游平原 \\
5.北疆凹陷平原 & 5.1 古尔班通古特(准噶尔)盆地 \\
& 5.2 乌苏一精河盆地 \\
& 5.3 布尔津一哈巴河一吉木乃盆地 \\
6.南疆凹陷平原与吐 & 6.1 塔里木河冲积平原(塔克拉玛干盆地) \\
哈盆地 & 6.2 托克拉克一布古里高地 \\
& 6.3 库鲁克一克孜勒苏高地 \\
& 6.4 吐哈盆地 \\
7.青藏高原北部凹陷 & 7.1 柴达木盆地 \\
平原与山原区 & 7.2 昆仑山高山与芫塘高原 \\
\hline
\end{tabular}

表 3 砾质覆盖体的成因类型

Tab.3 Formation types of gravel covers

\begin{tabular}{ll}
\hline \multicolumn{1}{c}{ 主导成因 } & \multicolumn{1}{c}{ 侵蚀/堆积类型与砾型 } \\
\hline 1.高原风蚀剥蚀残积堆积 & 1.1 剥蚀残积粗砾质堆积 \\
型(高原残积堆积型) & 1.2 剥蚀残积一坡积砾石、粗砾质堆积 \\
& 1.3 剥蚀残积一坡积一洪积砾质堆积 \\
& 1.4 剥蚀残积一洪积砂砾质堆积 \\
2.山麓山洪侵蚀堆积型 & 2.1 坡积一洪积砾石、粗砾质堆积 \\
(山麓侵蚀堆积型) & 2.2 洪积粗砾质堆积 \\
& 2.3 洪积一冲积砂砾质堆积 \\
\hline
\end{tabular}

大青山以北、狼山以东、北至蒙古人民共和国国 界。该区远离海洋, 在干旱与风力吹蚀作用下, 地 面残留砾质覆盖体, 发育为剥蚀残积砾质戈壁。

\section{I $1_{1}$ 二连浩特一苏尼特右旗剥蚀残积砾质戈 壁亚地区 \\ 该亚地区戈壁大片分布于高原剥蚀面上,集中 分布在二连浩特一苏尼特右旗一朱日和连线以西，}


表4 中国戈壁分区系统

Tab.4 Regionalization of stony deserts in China

\begin{tabular}{|c|c|c|}
\hline 第一级(区) & 第二级(地区) & 第三级(亚地区) \\
\hline \multirow{11}{*}{$\begin{array}{l}\text { I. 温性干旱极干旱戈 } \\
\text { 壁区 }\end{array}$} & I 1 内蒙古高原西部干旱戈壁地区 & I $1_{1}$ 二连浩特一苏尼特右旗剥蚀残积砾质戈壁亚地区 \\
\hline & I 2 阿拉善高原干旱极干旱戈壁地区 & 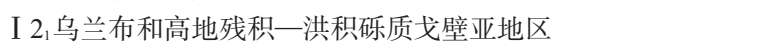 \\
\hline & & I $2_{2}$ 雅玛雷克高原残积一洪积砂砾质戈壁亚地区 \\
\hline & & I 2腾格里高地残积一洪积砂砾质戈壁亚地区 \\
\hline & & I 24巴丹吉林高地残积粗砾质戈壁亚地区 \\
\hline & & I 25居延盆地台地剥蚀一洪积砾质戈壁亚地区 \\
\hline & I 3 河西走廊东中部干旱极干旱戈壁地区 & I 31石羊河流域中下游平原洪积冲积砂砾质戈壁亚地区 \\
\hline & & I 32黑河流域中下游平原洪积粗砾质戈壁亚地区 \\
\hline & I 4 北疆盆地干旱极干旱戈壁地区 & I 4,准噶尔盆地东部剥蚀一洪积砾质戈壁亚地区 \\
\hline & & I 42乌苏一精河盆地山前洪积一冲积砂砾质戈壁亚地区 \\
\hline & & I $4_{3}$ 布尔津一哈巴河一吉木乃盆地洪积一冲积砂砾质戈壁亚地区 \\
\hline \multirow{6}{*}{$\begin{array}{l}\text { II . 暖性干旱极干旱戈 } \\
\text { 壁区 }\end{array}$} & II 1 鄂尔多斯高原西部干旱戈壁地区 & II 1 贺兰山东麓冲积——洪积砂砾质戈壁亚地区 \\
\hline & II 2 河西走廊西部极干旱戈壁地区 & II 2 敦煌一库姆塔格残积一洪积砾质砂砾质戈壁亚地区 \\
\hline & II 3南疆盆地极干旱戈壁地区 & II 3 塔克拉码干盆地洪积坡积砾质砂砾质戈壁亚地区 \\
\hline & & II 3,喀什山前平原洪积坡积砾质戈壁亚地区 \\
\hline & & II 3 $3_{3}$ 天山南麓与库鲁克库木洪积坡积砾质戈壁亚地区 \\
\hline & & II 34吐一哈盆地剥蚀一残积粗砾质戈壁亚地区 \\
\hline III. 青藏高原北部高原 & III 1 柴达木盆地极干旱戈壁地区 & III $1_{1}$ 柴达木盆地剥蚀一坡积一洪积砾质砂砾质戈壁亚地区 \\
\hline $\begin{array}{l}\text { 亚寒性干旱极干旱戈 } \\
\text { 壁区 }\end{array}$ & III 2 昆仑山一㒸塘高原高山高原戈壁地区 & III 2 1 昆仑山一芫塘高原高寒残积一坡积碎石、砾质戈壁亚地区 \\
\hline
\end{tabular}

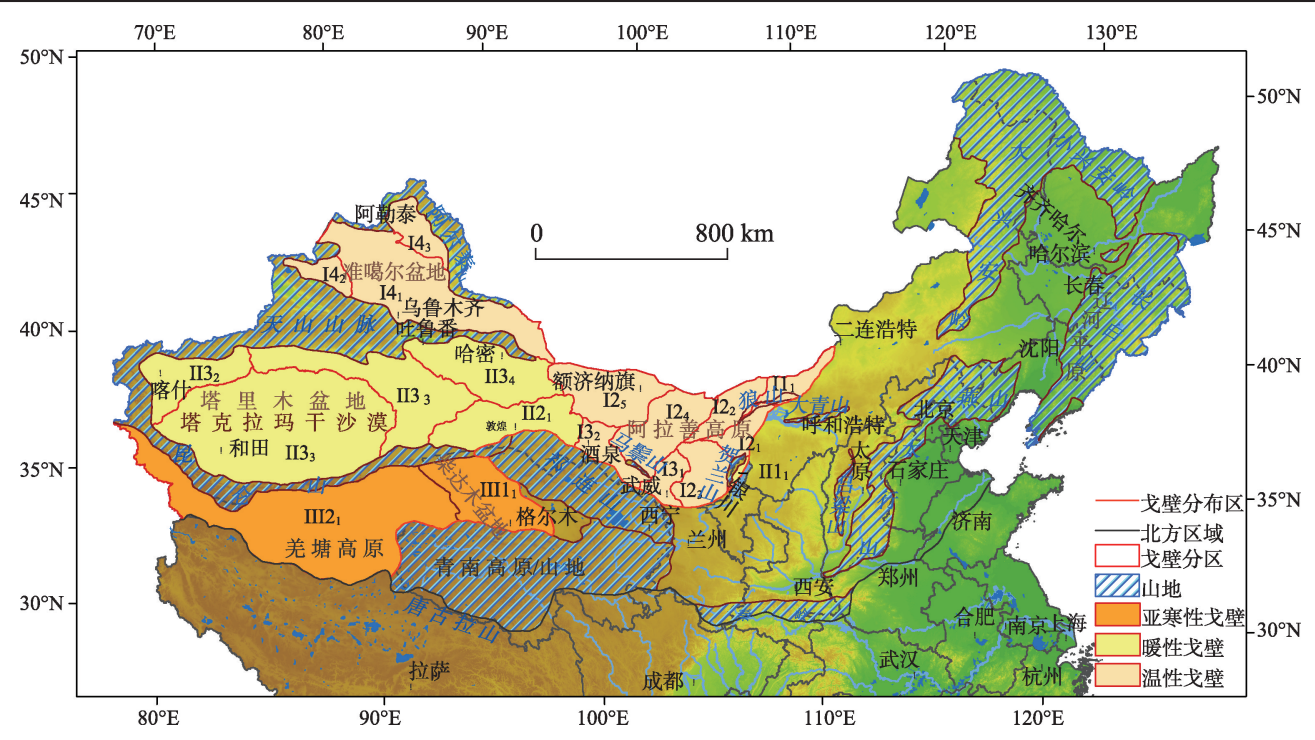

图 1 中国北部区域戈壁分区与山地分布图

Fig.1 Division of stony deserts and distribution of mountainous areas in northern China

狼山山脉以东、白乃庙一白云鄂博一海流图连线以 北至蒙古国界区域, 地形主体为乌兰察布高原, 海 拔 1000 1500 m。气候干早, 年降水量 120 250 $\mathrm{mm}$, 年均蒸发量 $2500 \mathrm{~mm}$ 以上, $\geqslant 10^{\circ} \mathrm{C}$ 年积温 $2200 \sim 2700^{\circ} \mathrm{C}$, 干燥度 $K$ 值 4.0 以上。年大风(8级)日 数超过 50 天, 高原面上呈现大面积戈壁景观, 覆盖 体以砾质为主。植被为旱生的戈壁针茅(Stipa gobi$c a$ )、荒漠锦鸡儿(Caragana przewalsRii)、戈壁短舌 菊 (Brachanthemum gobicum)、半日花 (Helianthemum soogoricum)、刺旋花 (Convolvulus tragacan-
thoidesTurcz)、木麻黄(Ephedra eguisetina) 等, 盖度 不足 $10 \%$ 。土壤发育成荒漠淡棕钙土, 整个剖面含 有多量粗砂与砾石, 砾面具不明显灰色漆漠, 石膏 化、积盐化过程明显, 积累层位高, 与荒漠灰棕漠土 相比, 其荒漠化程度相对较轻, 土体内未形成盐盘 淀积。

\section{2 阿拉善高原干旱极干旱戈壁地区}

该地区大地构造属阿拉善地台, 为基底稳定的 剥蚀干燥高平原。戈壁集中连片分布于贺兰山以 西、河西走廊北山以北、玉门北部残山马鬃山以东、 
北抵中一蒙国界地区。高平原上分布着如雅布赖 山等若干老年期干燥剥蚀低山与丘陵, 气候温性干 旱极干旱, 受局地挠曲差异升降作用影响, 可进一 步分异出 5 个亚地区。

\section{2 乌兰布和高地残积一洪积砾质戈壁亚地区}

该亚地区范围南依贺兰山, 北西依狼山, 东傍 河套平原, 为一半封闭式高原。海拔高程 1000 $1200 \mathrm{~m}, \geqslant 10^{\circ} \mathrm{C}$ 年积温 $2700 \sim 3500^{\circ} \mathrm{C}$, 年均降水量 $<150 \mathrm{~mm}$, 干燥度 $K$ 值 5.0 以上, 属温性干旱气候。 戈壁主要发育在山前洪积倾斜平原上, 主要类型为 洪积砾质戈壁和冲积洪积砂砾质戈壁。自然景观 为草原化荒漠, 土壤发育为荒漠灰漠土, 具有薄浅 棕灰结皮层、褐棕色紧实层和石膏化积聚层(熊毅 等, 1990)。植被盖度低, 通常不足 10\%, 群落主要为 琵琶柴(Reaumuria soogorica)、戈壁针茅、驼线黎 (Ceratoides latens)、珍珠猪毛菜(Salsola passerina)、 假木贼(Anabasis brevifolia)、红砂(Reaumuria soongorica)、梭梭(Haloxylon ammodendron)等灌木、半灌 木群落。

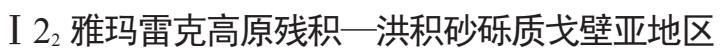

该亚地区位于狼山西北、北至蒙古国界。高原 波状起伏, 海拔 1000 1300 m, 大风日数 40 50天, 广泛分布残积砾质戈壁和洪积砂砾质戈壁, 是巴音 戈壁主要分布区域。年均气温 $5 \sim 8^{\circ} \mathrm{C}, \geqslant 10^{\circ} \mathrm{C}$ 年积 温 $2100 \sim 2500^{\circ} \mathrm{C}$, 年均降水量 $<100 \mathrm{~mm}$, 干燥度 $K$ 值 5.0 以上, 是中国干早至极干旱区的过渡区域。生 长膜果麻黄(Ephedra przewalsrii)、合头草(Sympegma regelii)、梭梭、霸王(Zygophyllum xanthoxylon)、 红砂、驼线蔜等旱生极旱生群落, 总覆盖度 $5 \%$ $10 \%$ 。土壤荒漠化成土过程突出, 发育荒漠灰漠土 与荒漠灰棕漠土。地表呈黑色砾幕, 表土层具多孔 状结皮,亚表层为铁质化褐棕色或浅红棕色的紧实 层, 有弱粘化现象, 淋溶作用微弱, 上层石灰淀积现 象明显, 下层石膏淀积加强, 形成石膏积聚层。

\section{23 腾格里高地残积一洪积砂砾质戈壁地区}

该亚地区位处贺兰山以西,西北临雅布赖山、 北临巴音乌拉山和民勤北山、南临宁夏中卫县黄 河。戈壁广泛发育在剥蚀高原与低山、丘陵山麓洪 积堆积体上。海拔 1400 1600 m, 年大风日数 20 30 天。区域东南部年均气温 $6.5 \sim 7.5^{\circ} \mathrm{C}, \geqslant 10^{\circ} \mathrm{C}$ 年积 温 $2800 \sim 3000^{\circ} \mathrm{C}$, 年降水量 $<200 \mathrm{~mm}$, 戈壁体上干燥 度 $K$ 值 5.0 以上。自然景观为草原化荒漠, 主要植 被类型为旱生小乔木梭梭, 灌木甘蒙锦鸡儿( Caragana opulens)、四合木 (Tetraena mongolica), 驼线
藜、骆驼蓬(Peganum harmala) 等。成土过程荒漠化 明显, 土壤发育为荒漠淡棕钙土。西北部极干旱化 突出, 生长超旱生灌木和半灌木, 建群植物有霸王、 琵琶柴、裸果木(Gymnocarpos prezwlsrii)、四合木、 白梭梭(Haloxylon persicum)、短叶假木贼等, 土壤发 育为荒漠灰棕漠土, 具深厚砾质化堆积体, 砾表黑漆 化,亚表层铁质化作用明显,形成灰棕色坚实层。下 层石膏积聚强烈, 形成石膏积聚层。石膏积累是荒 漠化成土过程的重要标志和戈壁的重要生态特征。

\section{$12{ }_{4}$ 巴丹吉林高地残积粗砾质戈壁亚地区}

该亚地区位于雅布赖山以西、弱水东岸古鲁乃 湖以东、河西走廊北山北大山以北、拐子湖一古日 乃湖连线以南的广阔地域。行政区域位于阿拉善 右旗与额济纳旗境内。地势高六, 海拔高度 1300 $1800 \mathrm{~m}$ 。多大风, 年 8 级大风日数 40 50天以上。 气候极干旱, 年均气温 8.0 9.0 ${ }^{\circ} \mathrm{C}, \geqslant 10^{\circ} \mathrm{C}$ 年积温 $3200 \sim 3600^{\circ} \mathrm{C}$, 年降水量 $100 \sim 40 \mathrm{~mm}$, 干燥度 $K$ 值 7 12。戈壁主要发生于高原剥蚀残积砾质堆积体上, 砾表漆漠化特征明显,亚表层灰棕与红棕色铁质化 作用强烈, 构成坚硬紧实层。淋溶作用极弱, 表层 常见钙的淀积, 心土层石膏积聚强烈, 生境严酷, 植 被为超旱生灌木与半灌木, 主要类型为沙拐患 $(\mathrm{Cal}-$ ligonum alaschanicum)、霸王、梭梭、短叶假木贼等, 覆盖度不足 $10 \%$, 生态景观为温性荒漠景观。

\section{2 居延盆地台地剥蚀一洪积砾质戈壁亚地区}

该亚地区北与蒙古人民共和国接壤, 东为拐子 湖一查干乌拉山连线以西, 南至拐子湖一古日乃湖 一马鬃山连线以北, 西界为马䦊山一明水一芦草沟 连线。海拔 1000 2500 m, 年大风日数 50 75 天, 高 原面上残丘残山交错分布,黑河由南而北注人居延 海。盆地气温较高, 年均气温高于 $7.5^{\circ} \mathrm{C}$, 无霜期高 于 220 天, $\geqslant 10^{\circ} \mathrm{C}$ 年积温大于 $3500^{\circ} \mathrm{C}$, 属暖温型气 候。高原残山面上温度较低, 属温性型气候。降水 稀少, 年降水量不足 $50 \mathrm{~mm}$, 干燥度 $K$ 值 $>12$, 自然 景观为极干旱荒漠, 为典型的黑戈壁景观, 主要有 嘠顺戈壁、中央戈壁、吉格德查干戈壁。以洪积粗 砾戈壁面积居广,与剥蚀石质戈壁与冲积一洪积戈 壁呈复合分布。砾面黑漆漠发亮, 多为裸体戈壁, 植被极少, 盖度不足 5\%, 散生植被有荒漠锦鸡儿、 合头草、霸王、膜果麻黄等。土壤发育为棕漠土和 灰棕漠土, 通体粗骨质结构, 钙化、石膏化、盐盘化 特征明显。

\section{3 河西走廊东中部干旱极干旱戈壁地区}

该地区位于河西走廊东中部, 东起乌鞘岭、南 
以祁连山、北以河西走廊北山(龙首山一合黎山一 马鬃山)为界、西止于嘉峪关一黑青山一黑山头之 间地区, 含石羊河流域中下游和黑河流域中游区 域。大地构造南为北祁连福皱带, 北为阿拉善一河 西走廊北山台块隆起带, 河西走廊则为上述二带之 间的凹陷带。凹陷始于二叠纪与三叠纪, 其后堆积 了侏罗纪至第四纪的巨厚山前粗质洪积体与河流 冲积物(中国科学院自然区划工作委员会, 1959), 在 干旱、洪积、残积堆积体上, 广泛发育了戈壁景观。 根据戈壁形成的区域生态处境, 以大黄山一东大山 为界, 可划分为东部与中部二个亚地区。

\section{31 石羊河流域中下游平原洪积冲积砂砾戈 壁亚地区}

该亚地区位于河西走廊东部, 受石羊河及其支 流水系控制, 地貌呈河谷盆地展现。石羊河发源于 祁连山, 河流出山口后, 在山麓形成巨大洪积扇, 而 在缓平地段形成宽广冲积平原。有水源灌溉处形 成连片绿洲, 如古浪绿洲、武威绿洲、永昌绿洲、民 勤绿洲。在洪积扇与隆升台块上, 广泛发育了山前 洪积砂砾戈壁与高原剥蚀砾质戈壁。戈壁一般分 布于海拔 1300 1700 m 高原上, 年大风日数 20 30 天, 降水稀少, 极为干旱。以民勤为例, 年均降水量 $116.9 \mathrm{~mm}$, 年均蒸发量 $3700 \mathrm{~mm}, \geqslant 10^{\circ} \mathrm{C}$ 年积温 $3149.4^{\circ} \mathrm{C}$, 干燥度 $K$ 值 5.05 , 自然景观为中温带荒 漠。零星生长旱生超旱生植物, 主要物种有梭梭、 霸王、琵琶柴、木本猪毛菜(Salsola arbuscula)、膜果 麻黄、戈壁针茅等。土壤发育为灰棕漠土。全剖面 呈强碱性反应, 石灰表聚作用明显, 随深度向下减 少, 而石膏与硫酸盐向下层增加, 心土形成石膏积 聚层, 较为坚实(甘肃省土壤普查办公室, 1993)。

\section{32 黑河流域中下游平原洪积粗砾质戈壁亚地区}

该亚地区位于河西走廊中部, 东以大黄山一东 大山为界, 西以黑青山一黑山头一线为界, 大致为 黑河水系中游区域。区内名城有张掖、酒泉、嘉峪 关。黑河从南而北呈带状向北伸展至居延海, 河谷 两侧为山前洪积扇与高原, 海拔 1200 1700 m。多 北风和西北风, 年大风日数 20 30天。气候温性极 干旱, 以酒泉为例, $\geqslant 10^{\circ} \mathrm{C}$ 年积温 $2954.4^{\circ} \mathrm{C}$, 年降水 量 $85.3 \mathrm{~mm}$, 干燥度 $K$ 值 11.18 。戈壁广泛发育, 高 原面上发育了剥蚀残积砾质戈壁。砾石面上“沙漠 漆”鸟黑发亮, 当地称 “黑戈壁”, 祁连山山前侵蚀洪 积戈壁体上,发育了砂砾质戈壁,当地称“白戈壁”, 戈壁体表层为灰棕色铁质化形成的紧实层, 心土层 石膏化积聚常形成石膏淀积层。自然景观为温性
荒漠, 生长超旱生植被, 主要群落有泡泡刺(Nitrari a sphaerocarpa)、裸果木、沙拐束等, 植被覆盖度不 足 $5 \%$ 。

\section{4 北疆盆地干旱极干旱戈壁地区}

该地区东与阿拉善高原相连, 南邻天山山脉, 北为阿尔泰山, 西至哈萨克斯坦国界。大地构造为 古陆台, 基底为古生代加里东褶皱, 后经稳定成古 陆。受局部沉降作用、地堑作用以及外营力作用区 域差异影响,可划分为 3 个亚地区。

\section{4 准噶尔盆地剥蚀一洪积砾质戈壁亚地区}

该亚地区戈壁分布在阿尔泰一北塔山山麓洪 积扇、盆地西缘山麓洪积扇、天山北麓山麓洪积扇 以及准噶尔盆地东部陆台上。山麓洪积扇上物质 为山洪侵蚀堆积体, 戈壁发育为坡积一洪积砾石、 粗砾质戈壁。陆台上的物质为风蚀残积堆积体, 戈 壁发育为剥蚀一残积粗砾质戈壁,著名戈壁有诺敏 戈壁、将军戈壁、二百四戈壁、淖毛湖戈壁。戈壁区 气候温性干旱极干旱, 年大风日数 20 50天。年均 气温 $3.5 \sim 7.5^{\circ} \mathrm{C}, \geqslant 10^{\circ} \mathrm{C}$ 年积积温 $3000 \sim 3500^{\circ} \mathrm{C}$, 年降 水量 70 140 mm, 温度从盆地东南向西北降低, 降 水则从东南向西北增多。干燥度 $K$ 值 $4 \sim 10$, 东部陆 台最为干旱。山体侵蚀洪积扇上部地下水位深, 干 旱、极干旱作用下, 发育成荒漠灰漠土,具有砾表漆 漠化,亚表层灰棕色铁质化, 心土层石膏淀积等特 征,而在洪积扇下部堆积体上,盐积化形成的盐盘 积聚明显,形成石膏盐盘戈壁。陆台残积堆积体上 发育成荒漠灰棕漠土(中国科学院新疆综合考察队 等, 1965)。植被由旱生超旱生灌木、半灌木植物构 成, 主要种群有梭梭、白梭梭、驼线藜、麻黄、沙拐 麥、假木贼等, 覆盖度不足 $10 \%$ 。

\section{4 2 乌苏一精河盆地山前洪积一冲积砂砾质 戈壁亚地区}

该亚地区戈壁分布于奎屯河以西、阿拉套山以 南, 沿艾比湖呈环状分布于山前洪积扇上, 所辖县市 有奎屯、乌苏、精河、博乐等。海拔300 600 m, 大风 日数 40 50天, 气候温性极干旱。以精河为例, 年均 气温 $6.0^{\circ} \mathrm{C}, \geqslant 10^{\circ} \mathrm{C}$ 年积温 $3582^{\circ} \mathrm{C}$, 年均降水量 91 $\mathrm{mm}$, 干燥度 $K$ 值 9.72 。在干旱、大风与山前洪积粗 砾质堆积体上, 发育了冲积一洪积砂砾戈壁。土壤 为灰棕荒漠土, 砾表具不明显漆膜, 亚表层铁质化 染色显著, 石膏与盐分在心土层淀积明显, 常形成 石膏盐盘积聚层, 强碱性反应。生长旱生超旱生植 物, 主要种群有白梭梭、沙拐患、苦艾蒿(Artemisia lavandulaefolia) 等, 盖度不足 $10 \%$, 生产潜力低下。 


\section{43 布尔津一哈巴河一吉木乃盆地洪积一冲 积砂砾质戈壁亚地区}

该亚地区范围位于准噶尔盆地西北的萨乌尔 山与阿尔泰山之间,西止于中一哈国界。戈壁分布 于山麓冲积一洪积扇上, 海拔 500 800 m。区域气 候温性干旱, 以哈巴河县为代表, 年均气温 $4.0^{\circ} \mathrm{C}$, ? $10^{\circ} \mathrm{C}$ 年积温 $2678.6^{\circ} \mathrm{C}$, 年均降水量 $86.6 \mathrm{~mm}$, 干燥度 $K$ 值 4.95。山前冲积一洪积扇形地广泛发育, 从上 部至下部, 堆积体由粗砾堆积逐渐过渡至砂砾堆 积。土壤由灰棕荒漠土和荒漠淡棕钙士构成, 具有 砾表孔状结皮、褐棕色坚实层、石膏聚积层等基本 剖面发生层(中国科学院新疆生物土壤沙漠研究 所, 1991)。植被为早生超旱生种群, 主要有假木 贼、梭梭、麻黄、霸王等, 盖度不足 $10 \%$, 生态环境脆 弱,植被破坏后,难于恢复。

\section{II . 暖温性干旱极干旱戈壁区}

该区指发育于暖温带干旱极干旱区的戈壁, 含 宁夏贺兰山东麓冲积一洪积戈壁、河西走廊敦煌一 库姆塔格残积一洪积戈壁、塔克拉玛干盆地洪积坡 积戈壁、喀什山前平原洪积坡积戈壁、天山南麓与 库鲁克库木洪积坡积戈壁、吐一哈盆地剥侵蚀一残 积戈壁。

\section{1 鄂尔多斯高原西部干旱戈壁地区}

鄂尔多斯高原位于内蒙古黄河中游后套以南、 黄土高原以北、贺兰山以东的区域, 构造上属稳定 陆台, 受挠曲差异升降影响, 地面波状起伏, 平均海 拔 1000 1200 m。受降水由东向西减少制约, 气候 由东部半干旱区向西部干旱区分异, 西部贺兰山东 麓出现干旱冲积一洪积砂砾质戈壁。

\section{II $1_{1}$ 贺兰山东麓冲积一洪积砂砾质戈壁亚地区}

该亚地区戈壁发育在贺兰山东麓山前冲积一 洪积扇形地上, 北抵石咀山, 南止于青铜峡。贺兰 山为一强烈隆升禇皱断块山, 其东侧为断陷作用形 成的宁夏冲积平原,平原与山体间发育了宽广的冲 积一洪积扇, 扇坡较陡, 有巨厚的砾质一砂砾质堆 积体, 在气候干旱、大风频繁状态下, 洪积扇上部发 育了砾质戈壁,下部发育了砂砾质戈壁。戈壁属暖 性戈壁, 以银川为例, 年均气温 $8.5^{\circ} \mathrm{C}, \geqslant 10^{\circ} \mathrm{C}$ 年积温 $3296.8^{\circ} \mathrm{C}$, 年均降水量 $189.9 \mathrm{~mm}$, 干燥度 $K$ 值 4.05 。 戈壁通体为粗骨质,表层具片状结皮,亚表层及心 土层石膏和盐分积聚明显, 石灰反立强烈, 但未形 成盐盘。植被稀疏, 生长草原化荒漠群落植被, 主 要种群有戈壁针茅、红砂、阿拉善锦鸡儿、驼线黎 等, 盖度不足 $10 \%$,生态脆弱, 生产潜力低下。

\section{2 河西走廊西部极干旱戈壁地区}

该地区位于河西走廊西部,由于戈壁形成发生 条件与河西走廊东、中部显著不同, 气候属暖温性 极干旱类型,单独划分为一个独立的亚地区。

\section{2 敦煌一库姆塔格残积一洪积砾质砂砾质 戈壁亚地区}

该亚地区范围界于西祁连一阿尔金山以北,甘 新交界(罗布泊)以东, 嘉峪关黑青山以西,马䦊山以 南。区内著名城镇有敦煌、安西、玉门。暖温性极 干旱气候, 以敦煌为代表, 年日照 3247.1 小时, $\geqslant$ $10^{\circ} \mathrm{C}$ 年积温 $3611.3^{\circ} \mathrm{C}$, 年均降水量 $36.8 \mathrm{~mm}$, 年均蒸 发量 $2490.6 \mathrm{~mm}$, 干燥度 $K$ 值 31.14 。水系主要为疏 勒河内流水系,亦有众多短小季节性小河。戈壁集 中分布于马鬃山一北山一带高原残山及祁连一阿 尔金山麓冲积一洪积体上。马䦊山一带高原剥蚀 残山海拔 1100 1400 m, 强辐射、高蒸发下发育了剥 蚀残积粗砾质戈壁, 土壤为石亳棕漠土, 砾面铁锰 黑幕漆发亮,呈现“黑戈壁”景观,为中国黑戈壁称 谓的起源区。戈壁通体为粗骨质残积体,亚表层呈 棕红色, 为铁氧化聚积层, 坚实; 其下为石膏积聚 层, 石膏呈块状体淀积, 坚实, 再下为粗砾母质层。 祁连一阿尔金山麓洪积堆积体上发育了冲积一洪 积粗砾一砂砾堆积, 洪积扇上部发育为石膏棕漠 土,洪积扇中下部发育为石膏盐盘棕漠土, 是最干 旱条件与可溶盐丰富母质下形成的戈壁。植被覆 盖度低,一般低于 $10 \%$, 主要种群有合头草、霸王、 膜果麻黄、红砂、琵琶柴等。

\section{3 南疆盆地极干旱戈壁地区}

该地区处于天山山脉以南,昆仑山一阿尔金山 以北、帕米尔高原以东, 东接 II 2 亚地区, 含塔里木 盆地和吐一哈盆地, 整个区域为暖温带极干旱区。 塔里木盆地的地质基础是寒武纪地台, 吐一哈盆地 为中天山东段南缘的凹陷盆地，二者虽在构造成因 上有别, 但都深居内陆, 平均海拔、干旱程度、生态 背景、戈壁成因与特征相似, 故将其归为一个地区。

\section{3 塔克拉玛干盆地洪积坡积砾质砂砾质戈} 壁亚地区

该亚地区范围为: 塔里木河以南、昆仑山中东 段以北、塔河下游一阿尔金山连线以西,叶尔芫河以 东区域。戈壁集中连片发育在昆仑山北麓若芫一和 田一叶城海拔 800 1200 $\mathrm{m}$ 的山前洪积一冲积堆积 体上。气候暖温极干旱, 年日照 3000 小时以上, $\geqslant$ $10^{\circ} \mathrm{C}$ 年积温 $4000 \sim 5000^{\circ} \mathrm{C}$, 年均降水量 30 70 mm, 年均蒸发量 $3000 \mathrm{~mm}$ 以上,干燥度 $K$ 值 $15 \sim 50$ 。以 
和田为例, 年均降水量 $27.3 \mathrm{~mm}, \geqslant 10^{\circ} \mathrm{C}$ 年积温 $4360.9^{\circ} \mathrm{C}$, 干燥度 $K$ 值 25.5 ; 若芫年均降水量 13.8 $\mathrm{mm}, \geqslant 10^{\circ} \mathrm{C}$ 年积温 $4353.9^{\circ} \mathrm{C}$, 干燥度 $K$ 值 50.48 。区 内年大风日数 20 30天。在极端干旱与强日照、多 大风条件下, 洪积扇砾质堆积体上发育了石膏棕漠 土戈壁, 洪积一冲积砂砾质堆积体上, 发育了石膏 盐盘棕漠土戈壁, 剖面构型主要由砾幕与薄多孔状 结皮层、浅红棕色铁质化染色紧实层、石膏淀积层 或石膏盐盘积聚层, 最下为粗砾质母质层构成。植 被覆盖度极低, 通常低于 5\%, 主要为超早生灌木和 半灌木, 建群植物有霸王、琵琶柴、短叶假木贼、麻 黄、梭梭等。

\section{32 喀什山前平原洪积坡积砾质戈壁亚地区}

该亚地区戈壁主要分布于叶尔差河以西、托什 干河以南, 西至帕米尔高原东麓的山前坡积一洪积 一冲积平原上海拔 900 1300 m, 气候暖温极干旱。 以喀什为例, $\geqslant 10^{\circ} \mathrm{C}$ 年积温 $4250.5^{\circ} \mathrm{C}$, 年均降水量 $44.5 \mathrm{~mm}$, 干燥度 $K$ 值 15.28 , 年大风日数 20 30天。 堆积体以砾质为主, 植物以假木贼、麻黄、琵琶柴等 超早生灌木半灌木为主, 覆盖度极低, 不足 $5 \%$ 。土 壤为砾质石膏棕色荒漠土, 具有 $1 \mathrm{~cm}$ 左右褐色结皮 层, 1 5 cm 乳黄色染色紧实层, 10 15 cm 的过渡层, 其下为约 $30 \mathrm{~cm}$ 的石膏淀积层, 石膏呈粗纤维状结 晶附于砾体中间。土壤淋溶作用弱, 碳酸钙等可溶 盐在表层积聚明显, 向心土逐渐减少。生态环境十 分脆弱, 植被破坏后, 极难恢复。

\section{3 . 天山南麓与库鲁克库木洪积坡积砾质戈 壁亚地区}

该亚地区戈壁主要分布于塔里木河干流以北、 阿克苏河以东、吐鲁番盆地南界觉罗塔格山以南地 区, 沿天山山脉冲积一洪积扇与库鲁克塔格高地发 育, 海拔 800 1400 m, 气候暖温极干旱。以库尔勒 为例, $\geqslant 10^{\circ} \mathrm{C}$ 年积温 $4273.8^{\circ} \mathrm{C}$, 年均降水量 $44.6 \mathrm{~mm}$, 干燥度 $K$ 值 16.87 , 年大风日数 30 35 天, 自然地带 为暖温带荒漠棕漠土地带。植被为超旱生膜果麻 黄、泡泡刺、沙拐苯、霸王等群落,覆盖度不足 5\%。 戈壁可分为两大类:一是发育于天山南麓洪积扇上 的戈壁为砾质与砂砾质戈壁, 在干热与风力作用 下, 淋溶弱, 石膏积聚于亚表层, 形成石膏棕漠土戈 壁, 可溶盐表聚性较枪, 向下有減少; 二是发育于库 鲁克塔格高地的戈壁, 主要为风蚀剥蚀残积砾质戈 壁, 通体物质组成较粗, 干热与高辐射条件下, 形成 石亳盐盘棕漠土戈壁, 表层为黑褐色铁锰结皮层, 厚不超过 $1 \mathrm{~cm}$, 淋溶作用极弱, 石膏与可溶盐于心
土层胶结为石膏盐盘层, 坚实, 向下即为风化砾质 母质层。

II $3_{4}$ 吐一哈盆地残积一洪积粗砾质戈壁亚地区

该亚地区由哈密盆地与吐鲁番盆地戈壁群组 成。区域范围北为东天山, 东界哈密盆地东侧的星 星峡一明水一马莲井连线,南为吐鲁番盆地南界的 觉罗塔格山, 西南与 II 3 亚地区相连。气候暖温极 干旱。以哈密为例, 年均温 $9.8^{\circ} \mathrm{C}, \geqslant 10^{\circ} \mathrm{C}$ 年积温 $4038.3^{\circ} \mathrm{C}$, 年均降水量 $34.6 \mathrm{~mm}$, 干燥度 $K$ 值 28.14 ; 吐鲁番, 年均温 $13.4^{\circ} \mathrm{C}$, 日照 3000 小时以上, $\geqslant 10^{\circ} \mathrm{C}$ 年积温 $5391.3^{\circ} \mathrm{C}$, 年均降水量 $16.4 \mathrm{~mm}$, 干燥度 $K$ 值 74.36 , 被称为中国的旱极。自然地带为暖温性极干 旱荒漠地带, 生长超旱生植物, 主要类型有琵琶柴、 裸果木、泡泡刺、霸王等群落, 盖度不足 $5 \%$ 。戈壁 广泛发育于盆地周边洪积扇及风蚀残丘上,以残积 一洪积粗砾质堆积体为主, 著名戈壁有南湖戈壁、 嘎顺戈壁、三间房戈壁。通体由砂砾质组成,表层 具荒漠结皮,结皮层下为棕红色染色层, 其下的心 土层为石膏结晶层, 土壤发育为石膏棕色荒漠土。

\section{III 青藏高原北部高原干旱极干旱戈壁区}

青藏高原作为区域整体, 是第三纪才从古地中 海 (特提斯海)退出而成陆, 并持续隆升, 目前为 4500 5000 $\mathrm{m}$ 以上的年轻高原, 山峰多在 $6500 \mathrm{~m}$ 以 上。在隆升背景下, 还伴随着区域性差异断块运 动,形成盆地,如柴达木盆地。由于地域广阔而高 䇯, 自然环境从东南向西北呈现亚热带湿润(森 林)一高原半湿润(森林灌丛草原)一高原半干旱(高 寒草原)一高原干旱(高寒荒漠)的分异(中国科学院 青藏高原综合考察队, 1982; 申元村等, 1991)。戈 壁出现于青藏高原北部高寒干旱区。依据戈壁分 布的地域区位,可划分出两个地区。

\section{1 柴达木盆地极干旱戈壁地区}

柴达木盆地位于青藏高原东北部,海拔 2680 $3300 \mathrm{~m}$, 周围山体海拔3300 5500 m, 是封闭式内陆 盆地, 具有亚寒干旱气候特征。盆地基座东西长约 $850 \mathrm{~km}$, 南北宽约 $250 \mathrm{~km}$, 自然地域分异出东南部半 干旱荒漠草原和西部干旱荒漠两个自然地带。戈 壁广泛分布于盆地西部干旱荒漠自然地带内。

\section{III $1_{1}$ 柴达木盆地剥蚀一坡积一洪积砾质砂砾 质戈壁亚地区}

该亚地区戈壁分布于盆地香日德脱土山一怀 头他拉连线以西,沿南部布尔汗布达山北麓洪积倾 斜平原, 北部阿尔金山一西祁连山山前洪积倾斜平 原连绵分布。戈壁分布区年均温 $1.1 \sim 4.4{ }^{\circ} \mathrm{C}, \geqslant 10^{\circ} \mathrm{C}$ 
年积温 900 2100 ${ }^{\circ} \mathrm{C}$, 年相对湿度小于 $35 \%$, 年均降 水量 17.8 84.6 mm, 年蒸发量 2100 3300 mm, 年大 风日数 25 70 天, 干燥度 $K$ 值大于 10 , 属亚寒极干 旱类型(申元村, 1987)。生长超早生植被群落, 主要 种群有梭梭、红砂、沙拐柊、优若藜、木紫苑(Asterothamus centrali-asiaticus)等, 盖度不足 5\%。土壤发 育为灰棕荒漠土, 地表砾石具黑色漆膜, 其下为受 铁质化染色的紧实层。依据石膏积聚与可溶盐积 累地段差异, 洪积扇上部粗砾质戈壁上发育为普通 灰棕漠土戈壁,洪积扇中部与高阶地砾质戈壁上, 发育成石膏灰棕漠土戈壁, 洪积扇下部洪积一冲积 砂砾质堆积体上, 发育成石膏盐盘灰棕漠土戈壁 (青海省农业资源区划办公室, 1997)。

\section{2 昆仑山一差塘高原高山高原戈壁地区}

该地区处于西藏的最北缘, 北部是昆仑山脉, 海拔 $6000 \mathrm{~m}$ 以上, 现代冰川广泛发育。南部是芫塘 高原, 海拔 $4900 \mathrm{~m}$ (北部) 4500 m(南部)。高原波状 起伏, 残丘孤山众多, 湖泊星罗棋布, 多为咸水湖, 河流短小, 均为季节性内陆河流。气候高寒干旱, 年均气温 $0 \sim 3{ }^{\circ} \mathrm{C}, 1$ 月均温 $-10^{\circ} \mathrm{C}$ 以下, 7 月均温 $10 \sim$ $12^{\circ} \mathrm{C}$, 无真正夏季。降水稀少, 自然地带发育成高 寒荒漠草原与高寒荒漠(中国科学院青藏高原综合 科学考察队, 1982)。戈壁广泛分布于昆仑山一芫 塘高原高山高原区内。

\section{2, 昆仑山一羌塘高原高寒残积一坡积碎石、 砾质戈壁亚地区}

该亚地区戈壁广泛发育于昆仑山麓冰碛洪积 裙中下部与芫塘高原剥蚀残积体上, 通体几乎为石 砾质堆积, 土壤发育为高寒漠土, 地表具孔状荒漠 结皮, 石膏和易溶盐含量较低, 且富集于上部, 形成 非典型的石膏积聚层, 其下即迅速过渡到母岩层。 植被覆盖度极低, 不足 $5 \%$, 以低矮匍生草本为特 征, 主要种群有垫状驼线藜(Ceratoides compacta)、 垫状无茎荠(Pegaeophyton scapiflorum)、山虫缀 (Arenaria monticola)、西藏亚菊(Ajania tibetica) 等 (熊毅等, 1990)。

\section{6 结论}

戈壁是中国北方广泛分布的一种独特地理景 观, 直至目前还没有开展过系统的分区研究。本文 根据戈壁基本特征与形成过程, 将戈壁定义为: 地 表由砾石、砂砾覆盖, 土壤发育微弱、石膏化过程和 积盐过程突出, 表层具极不稳定孔状结皮、其下为
棕红色紧实层及石膏层, 植被覆盖稀疏、盖度通常 不足 $10 \%$, 生长旱生、极旱生灌木一半灌木植物的 一种地理景观。其形成发生的学术界定是: 戈壁仅 形成发生于干旱一特干旱气候类型,地貌条件为干 旱高原面、残丘与山体洪一冲积扇中上部,洪积扇 以上的山体不会出现戈壁; 砾质覆盖体的成因主要 为剥蚀残积与侵蚀堆积两种类型。依据戈壁发生 的地理分异规律,选择层次不同区划指标,构建级 别不同的区划体系。采用 $\geqslant 10^{\circ} \mathrm{C}$ 积温与干燥度 $K \geqslant 4$ 为指标, 将中国戈壁分布区域划分为温性干旱极干 旱戈壁区、暖温性干旱极干旱戈壁区、青藏高原北 部高寒干旱极干早戈壁区(一级区); 以区域地貌单 元为依据划分出 9 个地区 (二级区); 以砾质覆盖体 成因类型划分出 19 个亚地区 (三级区); 今后, 还可 根据土壤和植被的地域分异进一步划分出若干小 区(四级区)。

\section{参考文献(References)}

甘肃省土壤普查办公室. 1993. 甘肃土壤[M]. 北京: 农业出 版社. [Gansusheng turang pucha bangongshi. 1993. Gansu turang[M]. Beijing, China: Agriculture Press.]

卢琦. 2000. 中国沙情 [M]. 北京: 开明出版社. [Lu Q. 2000 . Zhongguo shaqing[M]. Beijing, China: Kaiming Press.] 潘晓玲, 党荣理, 伍光和. 2001. 西北干旱荒漠区植物区系地 理与资源利用 $[\mathrm{M}]$. 北京: 科学出版社. [Pan X L, Dang R L, Wu G H. 2001. Xibei ganhan huangmoqu zhiwuquxi dili yu ziyuan liyong[M]. Beijing, China: Science Press.]

青海省农业资源区划办公室. 1997. 青海土壤[M]. 北京: 中 国农业出版社. [Qinghaisheng nongye ziyuan quhua bangongshi. 1997. Qinghai turang[M]. Beijing, China: China Agricultural Press.]

申元村. 1987. 柴达木盆地自然环境与自然资源开发利用的 初步研究 [J]. 自然资源学报, 2(2): 133-140. [Shen Y C. 1987. The natural environment of Chai Da Mu Basin and the research of resources exploitation[J]. Journal of Natural Resources, 2(2): 133-140.]

申元村, 王秀红, 丛日春, 等. 2013. 中国沙漠、戈壁生态地理 区划研究 [J]. 干旱区资源与环境, 27(1): 1-13. [Shen Y C, Wang X H, Cong R C, et al. 2013. Eco-geographical zoning of deserts and Gobi in China[J]. Journal of Arid Land Resources and Environment, 27(1): 1-13.]

申元村, 向理平. 1991. 青海省自然地理 [M]. 北京: 海洋出 版. [Shen Y C, Xiang L P. 1991. Qinghai ziran dili[M]. Beijing, China: Ocean Press.]

王伯恭. 1999. 中国百科大辞典[M]. 北京: 中国大百科全书 出版社. [Wang B G. 1999. Zhongguo baike dacidian[M]. Beijing, China: Encyclopedia of China Publishing House.] 吴正. 2009. 中国沙漠及其治理 [M]. 北京: 科学出版社. [Wu 
Z. 2009. Zhongguo shamo jiqi zhili[M]. Beijing, China: Science Press.]

熊毅, 李庆逵. 1990. 中国土壤 [M]. 2 版. 北京: 科学出版社.

[Xiong Y, Li Q K. 1990. Zhongguo turang[M]. 2nd ed.

Beijing, China: Science Press.]

赵松乔. 1985. 中国干旱地区自然地理[M]. 北京: 科学出版

社. [Zhao S Q. 1985. Zhonggguo ganhanqu ziran dili[M].

Beijing, China: Science Press.]

赵松乔, 杨利普, 杨勤业. 1990. 中国的干旱区 [M]. 北京: 科

学出版社. [Zhao S Q, Yang L P, Yang Q Y. 1990. Zhong-

guo de ganhanqu[M]. Beijing, China: Science Press.]

郑度, 等. 2007. 中国生态地理区域系统研究[M]. 北京: 商务印

书馆. [Zheng D, et al. 2007. Zhongguo shengtai dili quyu xitong yanjiu[M]. Beijing, China: The Commercial Press.]

郑度, 葛全胜, 张雪芹, 等. 2005. 中国区划工作的回顾与展望

[J]. 地理研究, 24(3): 330-344. [Zheng D, Ge Q S, Zhang

X Q, et al. 2005. Regionalization in China: retrospect and prospect[J]. Geographical Research, 24(3): 330-344.]

郑度, 杨勤业, 吴绍洪. 2015. 中国自然地理总论 [M]. 北京:

科学出版社. [Zheng D, Yang Q Y, Wu S H. 2015. Zhongguo ziran dili zonglun[M]. Beijing, China: Science Press.]
中国科学院青藏高原综合科学考察队. 1982. 西藏自然地理 [M]. 北京: 科学出版社. [Zhongguo kexueyuan Qingzang gaoyuan zonghe kexue kaochadui. 1982. Xizang ziran dili[M]. Beijing, China: Science Press.]

中国科学院新疆生物土壤沙漠研究所. 1991. 新疆土壤及土 地资源研究 $[\mathrm{M}$ ]. 北京: 科学出版社. [Xinjiang Institute of Biological Soil Desert of Chinese Academy of Sciences. 1991. Xinjiang turang ji tudi ziyuan yanjiu[M]. Beijing, China: Science Press.]

中国科学院新疆综合考察队, 等. 1965. 新疆土壤地理 $[\mathrm{M}]$. 北京: 科学出版社. [Zhongguo kexueyuan Xinjiang zonghe kaochadui, et al. 1965. Xinjiang turang dili[M]. Beijing, China: Science Press.]

中国科学院自然区划工作委员会. 1959. 中国地貌区划(初 稿) [M]. 北京: 科学出版社. [Work Committee of Physical Regionalization of the Chinese Academy of Sciences. 1959. Zhongguo dimao quhua (chugao)[M]. Beijing, China: Science Press.]

朱俊凤, 朱震达, 等. 1999. 中国沙漠化防治[M]. 北京: 中国 林业出版社. [Zhu J F, Zhu Z D, et al. 1999. Zhongguo shamohua fangzhi[M]. Beijing, China: China Forestry Press.]

\title{
Integrated physical regionalization of stony deserts in China
}

\author{
SHEN Yuancun', WANG Xiuhong ${ }^{1 *}$, CHENG Weiming ${ }^{2}$, WU Jinfeng ${ }^{1,3}$, LU Qi $^{4}$, FENG Yiming ${ }^{4}$ \\ (1. Key Laboratory of Land Surface Pattern and Simulation, Institute of Geographic Sciences and Natural \\ Resources Research, CAS, Beijing 100101, China; 2. State Key Laboratory of Resources and Environmental \\ Information System, Institute of Geographic Sciences and Natural Resources Research, CAS, Beijing 100101, \\ China; 3. University of Chinese Academy of Sciences, Beijing 100049, China; 4. Institute of Desertification, \\ China Academy of Forestry Sciences, Beijing 100091, China)
}

\begin{abstract}
Stony deserts are widely distributed in the arid and extremely arid regions in China. However, an integrated physical regionalization of these stony deserts has not been carried out. Based on a comprehensive analysis of the relationship between the characteristics and formation mechanism of stony deserts, the main features of stony deserts can be summarized as follows: land surface is covered with gravels; surface layer has porous thin desert crust, below which red brown compact and gypsum layers are found. Vegetation mainly includes arid and extremely arid shrubs and semi-shrubs with low coverage. Stony deserts only exist in arid and extremely arid regions with aridity index greater than 4 . Based on the regional differentiation of characteristics and formation conditions of stony deserts, this study selected indicators reflecting aridity and temperature, regional geology and geomorphology, and formation conditions and types of surface materials to classify the stony deserts into three first-level regions (temperate arid and extremely arid region, warm temperate arid and extremely arid region, and arid and extremely arid region in northern Tibetan Plateau); nine second-level regions (according to regional geological and topographical features), and 19 third- level regions (based on regional formation conditions and types of surface materials). Further division can be made based on regional differentiation of soils and vegetation.
\end{abstract}

Key words: stony desert; arid and extremely arid region; integrated physical regionalization 